\title{
The Wasatiyyah (Moderation) Concept: Its Implementation In Malaysia
}

Wan Kamal Mujani

The National University of Malaysia

Email: inawan@ukm.edu.my

\section{Ermy Azziaty Rozali}

The National University of Malaysia

Email: ermy@ukm.edu.my

Nor Jamaniah Zakaria

The National University of Malaysia Email: jamynia@yahoo.com

\section{Doi:10.5901/mjss.2015.v6n4s2p66}

\begin{abstract}
This article discusses the concept of Wasatiyyah which had been announced by Dato' Sri Mohd Najib bin Tun Abdul Razak and explains several implementations by the government of Malaysia relating to this concept. The purpose of this article is also to to determine the true meaning of the Wasatiyyah concept which the Prime Minister wishes to convey. This paper generally adopts a qualitative study approach through examination of books, journals and internet materials. The outcome of this writing finds that the intended meaning of Wasatiyyah which the Prime Minister wishes to convey is not a deflection of or deviation from the Islamic meaning, instead it has its own interpretation suitable in the context of Malaysian society. In addition, there are some government bodies established to apply this Wasatiyyah concept in Malaysia, besides conferences and seminars to publicize this concept.
\end{abstract}

Keywords: Wasatiyyah; moderate; Malaysia;

\section{Introduction}

The purpose of this article is to examine the Wasatiyyah concept introduced by the fifth Prime Minister of Malaysia, Mohd Najib bin Tun Abdul Razak in the month of September 2010. In addition, its purpose is also to study the meaning of Wasatiyyah from the Islamic perpective. Wasatiyyah here refers to moderation, middle, balance or the middle path approach. Its purpose is to balance a matter, in terms of thinking or behaviour so as not to be excessive or extreme. Mohd Najib bin Tun Abdul Razak has made Wasatiyyah as the support for the 1Malaysia Concept which aims to unify the multiethnic people in Malaysia. In this paper, all perspectives relating to the Wasatiyyah concept are analysed. Thus, based on this context, a study of the Wasatiyyah concept should be understood more deeply so that it will not be misinterpreted by any party.

\section{Wasatiyyah Concept According to Islam}

Wasatiyyah in Islam has long existed since the birth of the Islamic faith in this world. However, the concept of Wasatiyyah was not widely known in Malaysia until the fifth Prime Minister introduced this concept in government administration. In attempting to know the true meaning which the Prime Minister intended, it should be seen from all aspects suitable with the current situation.

Wasatiyyah originates from the Arabic root word, Wasat. In language terms, Wasat means middle, and the derivative word means just or fair, the best, the chosen (in quality), the finest (as an art) and respectable. An example of its expression is such as: the most Wasat means something which is the best, the most just and the chosen (Kling, 2011, p.1).

According to Mohamed Baianonie, Wasat has three meanings, namely, to be moderate, to be in the middle, and to 
be the best. Thus, when Allah s.w.t explains that the Muslims are a Wasat community, what is meant is moderation, middle way and the best people. Moderation in Islam shows that a Muslim should stabilise as much as possible their affairs and avoid extremist activities which cause disorder or chaos.

The essence of the Islamic Wasatiyyah concept is contained in many places in al-Quran such as Allah's statement in Surah al-Baqarah, verse 143 which means: And thus We have made you a just community that you will be as witnesses over the people and the Messenger will be a witness over you. And also in Surah al-Furqan, verse 67: And [they are] those who, when they spend, do so not excessively and not sparingly, but are ever, between that, [justly] moderate.

Surah al-Furqan, verse 67 also explains that moderation in religion as demanded by Allah s.w.t should be practised in daily life. If moderation were to be practised by the Islamic community, there would not be severely disturbing violence and extremism, a constraint to peace in the world today.

Actually, the term Wasatiyyah is taken and developed from the expression Ummatan Wasatan mentioned in alQuran, Surah al-Baqarah, verse 143 and it has a few meanings, namely, middle path (Abdulkarim Amrullah, 1982, p.333), justice, middle (Qutb, 2000, pp.295-297; Sya'rawi, 2004, p.474), moderate (Omar Khalid, 2009, p.108), the best position, most honourable, most perfect, (Ibn Kathir, 2003, pp.422-424; Hashem, 2006, p.1) and alternative (Basri, 2008, p.156).

Ummatan Wasatan is also interpreted as the Islamic community who receives the Prophet Muhammad's shariah, and the chosen and just community. Abdullah Basmeih (2001), states the meaning of Ummatan Wasatan with the following explanation: Ummatan Wasatan means the chosen and just community, and also means the middle community, that is, moderate in all ways or demeanour, not extreme and not obsessive in any religious belief, also in ethics and practice, and everything is in a state of stability, jointly viewed, learnt and worked in efforts encompassing issues of the world and the hereafter. Each person who stands in the middle while deeply and seriously considering matters around him, then his judgment and knowledge on the pros and cons of a matter are just, true and valid. Therefore, he is qualified to give an explanation or evidence to others whose circumstances are unlike his (M. Mazuki et al., 2013a; 2013b).

The meaning of the term Wasatiyyah is detailed by several other writers. For example, M. Quraish Shihab (1996) who states that Wasatiyyah means everything good and suitable with its object, that is, something good is in the position between two extremes. The extreme positions are then explained by Muhammad Haniff Hassan (2003) as being the extreme in harshness and the extreme in leniency.

Apart from M. Quraish Shihab, there are others who state that Wasatiyyah or Tawassut means the Muslim community must try their level best to be moderate in everything they do. According to N. S. S. Nik Salleh (2011), moderate means a condition which is not more and not less, that is a normal and calm situation. She adds that moderation also means to put something in its appropriate place or give something to the one entitled to it.It also means with justice or being just. Khadijah M. Khambali@Hambali et al. (2010) also have the view that Wasatiyyah is being just by putting something in its right place and hierarchy, balanced and in the middle between two different extremes.

In other words, Wasatiyyah means not having the attitude of Ghuluww and Tatarruf (excessive and obsessive) in embracing faith. Likewise in ethics and practice, everything is in a state of moderation and balance (Basmeih, 2001, p.55). In this matter, a person cannot be too obsessed with the world and neglect the hereafter or too fanatic about the hereafter and forget the world. Likewise, one cannot be so obsessed solely with acquiring wealth and forget other individuals who are less able.

Based on the explanation of the etymological meaning above, it is clear that the Muslim community may be described as a society just and moderate in its position. According to Sayyid Qutb (2000), the Muslim community is just in every meaning of justice whether in the meaning of goodness and advantage or the meaning of moderation or meaning of physically in the middle. Actually, the Muslim community is in the middle position. Thus, the Muslim community should not drift with materialism. The position of the Muslim community in the middle enables the Muslim community to balance between the spiritual and physical or material aspects, including all attitudes and actions (Shihab, 1996, pp.328-329).

The Muslim community becomes weak when fanaticism and taksub (obsession) towards a particular approach reaches an extreme level or liberalism becomes widespread (Tafrit dan Tasahul) undermining religious understanding and practice. Both these tendencies are deviations from Islamic teachings which are just and moderate (al-'Adl wa alWasat) (Abdul Majid, 2004). Thus, every matter in this world requires balance. When the element of balance is absent, various problems will arise (Munawwir, 1986, p.177).

After examining the meanings submitted by some researhers, it can be stated that the Wasatiyyah concept should be seen within a wider scope and more general meaning so that its use will suit various situations and not focus on only a single situation. 


\section{The Concept of Wasatiyyah Introduced by The Prime Minister}

Wasatiyyah in Islam has a very wide meaning as has been discussed above. Mohd Najib Tun Abdul Razak has used this concept in his own dimension to suit increasingly disturbing global issues. However, the principle thus used does not at all contradict the Islamic faith, instead there are some contents, direction and planning in the implementation of this concept which are consistent with the government's desire to realize a more harmonious unity among the multiracial, multireligious and multicultural society.

Mohd Najib Tun Abdul Razak states that the term Wasatiyyah simply means "non-extremist thinking" such as practised in government administration (Maslan, 2011). It may also be understood in a statement by Ahmad Maslan as follows: "Wasatiyyah is a movement pioneered by Dato' Sri Mohd Najib and is always mentioned by him not only within the country but also in his speeches overseas, the latest in Hawaii, United States of America. It has captured the attention of foreign leaders, but before it can be saleable abroad, it should be understood within this country by the leaders and people and in its connection with the 1Malaysia Concept." In addition, he also explained that understanding of Wasatiyyah is required because the term means moderation, middle and balance learning styles

The peak of Islamic manifestation based on the Wasatiyyah concept in Malaysia can be seen in the historical emergence and development of the glorious Islamic civilization including the implementation of an Islamic system in every aspect of life. Tolerance and the principle of social justice practiced in this country are consistent with Islamic principles and have succeeded in building a multiethnic society living in harmony and with mutual respect (M. Mazuki et al., 2014).

\section{Wasatiyyah in 1Malaysia Concept}

As the 1Malaysia concept is an idea or brainchild of the Prime Minister of Malaysia, Mohd Najib Tun Abdul Razak, then the definition needs prior reference to his explanation as follows: "We stand, we think and we act as a Malaysian race. And we take action based on the wishes of all ethnic groups in our country. This does not mean that we set aside affirmative policy, policy to help the Bumiputera as long as the policy is implemented in a fair way and gives consideration to Bumiputera who are eligible to be considered by the government. We depart from the earlier way of acting from within the ethnic walls that we have practised for so long" (National Policy Publications Division, 2010, p.3).

From Mohd Najib bin Tun Abdul Razak's explanation on this 1Malaysia concept, it can be concluded that this concept is about racial unification. Within it are contained three main thrusts, namely: principles of acceptance, of statehood and of social justice. The underlying principle of the Malaysia concept respects and upholds the principles of the Federal Constitution as well as the identity of each ethnic group in Malaysia. This means that the 1Malaysia concept is based on the Federal Constitution. The privileges of the Malays and Islamic faith will not be questioned, while the other races are free to practise their respective faiths and cultures. 1Malaysia means that the government will put people first and across all levels of society as well as ethnic groups in each corner of the homeland (Moner, 2010).

Based on an examination of the main principle contained in the 1Malaysia concept, 3 elements of Wasatiyyah are found to support it. Wasatiyyah elements are explained as follows:

\subsection{Wasatiyyah in the acceptance principle}

This principle means all Malaysians comprising of various ethnic groups are free to practise their respective faiths and ways of life. The Wasatiyyah concept is implemented in all aspects of life and one of them is the religious aspect. Faith or religion is exclusive in nature. Thus, this matter needs to be emphasized so as to avoid conflict in society and later correct it if necessary; and they like material which is of a more concrete, human, social or artistic nature.

In Malaysia, even though there are different religions and ways of life, there is mutual respect and acceptance of these differences. This principle of liberty in practicing a faith is Wasatiyyah. Although it is entrenched in the Federal Constitution that Islam is the official state religion, adherents of other faiths are not prevented from practising their respective faiths in peace and harmony.

Related to this matter, the 1Malaysia concept is seen to be in line with the historical formation of the Islamic state and civilization of Medina by the Prophet and Messenger of Allah p.b.u.h. The Charter of Medina agreed upon between the Prophet Muhammad p.b.u.h and the non-Muslim society highlights the spirit of tolerance for freedom of religion. The Prophet p.b.u.h gave freedom to the minority groups and to non-Muslims to practise their faith. This is consistent with a statement of Allah s.w.t in Surah al-Baqarah, verse 256 which means: "There is no compulsion in [acceptance of] the religion (Islam); The right course has become clear from the wrong So whoever disbelieves in Taghut and believes in 
Allah has grasped the most trustworthy handhold with no break in it. And Allah is Hearing and Knowing."

The above verse clearly proves that there is no element of coercion in Islam. Man may not be forced to enter Islam, but are invited to think. This is seen as parallel with the 1Malaysia Concept.The proof is in Article 3(1) of the Federal Constitution which enshrines Islam as the official state religion. The position of Islam is higher compared to other religions. Even though other religions are not stated in the Federal Constitution, they may be practised in peace and harmony. However, freedom of religion is not absolute. Clause (4) of Article 11 of the Federal Constitution gives the power to Parliament and other state legislative bodies to pass laws controlling propagation of other religions to Muslims (M. Adil, 2010).

\subsection{Wasatiyyah in the principle of statehood}

In order to strengthen unity, a Malaysian identity should take priority. In this context, the Malaysian language is a language which symbolises the Malaysian race comprising of various ethnicities. Even though the Malaysian language is the national language, it does not mean that other languages cannot be used or are marginalised. Instead, the people are encouraged to master foreign languages. This is proven in the case of national type vernacular (Chinese or Indian) schools which are still maintained even though a vision (Wawasan) school type based on the concept of unity is already established.

Unity as well as disparity are taken care of by following the Wasatiyyah concept which reflects balance, that is, not being excessive nor diminished. Extremism will cause destruction.

Extremism also leads to pettiness and close-mindedness towards differences of opinion. Clearly, implementation of the Wasatiyyah concept in the 1Malaysia concept is not, in the context of languages, favouring the identity of other races. It means not favouring only one language. Instead, the Malaysian Language is the identity of the Malaysian race which is the symbol and backbone of the nation that should be appreciated. People will find it difficult to accept this identity if it is politicized (Mujani et al., 2014a).

\subsection{Wasatiyyah in the principle of social justice}

The Malay term adil (just) is itself from an Arabic word al-'Adalah which has a similar meaning to Qist dan Wasat which means mid or middle. In Islam, social rights and public interest are much safeguarded besides individual rights. Social justice is an important aspect to engender goodness or Wasatiyyah in society. The principle of moderation is the soul and essence of the 1Malaysia concept which aims to foster unity among the people of different ethnicities. Wasatiyyah in the principle of social justice can be seen in two main aspects. First, Wasatiyyah in the distribution of political power and second, in the distribution of wealth. Both these aspects are explained below:

\subsubsection{Distribution of political power}

As a multiracial country, distribution of political power needs to represent all the ethnic groups. This is to avoid feelings of dissatisfaction towards the government which may lead to chaos. Every ethnic group is given the space to form its own political party. For example, UMNO represents the Malays, MCA the Chinese and MIC the Indians, and so on. The wisdom in distributing political power is clearly based on the Wasatiyyah concept.

In the Malayisan context, even though the Muslim-Malay form the majority, other groups such as the Chinese and Indians are also in the national leadership. It is clear here that the distribution of political power is based on the Wasatiyyah concept. Such a distribution of power helps to avoid excessive demands by a group for more power (Mujani et al., 2014b).

\subsubsection{Distribution of wealth}

All on this earth and in the sky belong absolutely to Allah s.w.t. This is how it is stated in Surah Ali 'Imran verse 109: To Allah belongs whatever is in the heavens and whatever is on the earth. And to Allah will [all] matters be returned. This verse clarifies that wealth is not the absolute wealth of any individual or group, instead it belongs to Allah s.w.t. Mankind is only holding wealth in trust as a consumer according to their needs in life. 


\section{Application of Wasatiyyah in State Administration}

The concept of Wasatiyyah is not just for introduction, but it is to be applied, appreciated and practised. Various programs have been created by the Prime Minister of Malayisa in the process of giving life to this concept which was introduced through particular agencies such as institutes and foundations in efforts to widen society's understanding regarding the Wasatiyyah concept. This includes organising of conferences, discourses and seminars on this concept (Ismail, 2012, p.1), such as the following:

\subsection{The Wasatiyyah Institute}

The Wasatiyyah Institute was established at national level on 17th January 2012 under the Prime Minister's Department in Kuala Lumpur. This institute has the role of focusing on the moderation and balance aspects through respect for democracy, regulations and laws, education, personal dignity and self-esteem a well as social justice.

\subsection{Global Movement of Moderates (GMM) Foundation}

Global Movement of Moderates (GMM) Foundation functions as a centre which initiates unification and dissemination of information as well as campaign materials to all parties who wish to participate in efforts against extremism, including governmental bodies and non-governmental organizations. In addition, it upholds the role of GMM as a unification centre to efforts against violence and extremism whether that mobilized by governmental bodies or non-governmental organizations (NGO).

\subsection{Discourse of Panel Thinkers on the Wasatiyyah Concept}

Discourse of Panel Thinkers on the Wasatiyyah Concept was held on the 20th May 2011. In the summary session of this discourse, members of panel thinkers reached an agreement to determine certain contents, direction and planning in the implementation of the Wasatiyyah concept consistent with the government's desire to create a more harmonious unity among the multiracial, multireligious and multicultural society. Global Movement of Moderates (GMM) Foundation functions as a centre which initiates unification and dissemination of information as well as campaign materials to all parties who wish to participate in efforts against extremism, including governmental bodies and non-governmental organizations. In addition, it upholds the role of GMM as a unification centre to efforts against violence and extremism whether that mobilized by governmental bodies or non-governmental organizations (NGO) (Mujani et al., 2014a).

\subsection{The National Seminar on Understanding Wasatiyyah and 1Malaysia}

The National Seminar on Understanding Wasatiyyah and 1Malaysia was inaugurated by Mohd Najib Tun Abdul Razak on 26th November 2011. Deputy Minister at the Prime Minister's Department who is also Information Chief of UMNO, Datuk Ahmad Maslan, said that this seminar analyzed more in-depth the meaning of Wasatiyyah and the meaning of 1Malaysia concept inspired by Mohd Najib. This inaugural seminar held at Dewan Tun Dr Ismail, Putra World Trade Centre, uncovered the Wasatiyyah concept. Among the aspects discussed in this seminar was how the Wasatiyyah concept is implemented in administration of religious affairs and how organizations may benefit from the practice of moderation.

\subsection{International Conference on Global Movement of Moderates (ICGMM)}

International Conference on Global Movement of Moderates (ICGMM) on the 17th to 19th January 2012 at the Kuala Lumpur Convention Centre, organised by the Alumni Society of International Islamic University of Malaysia (IIUM) with the goal of leading the world towards moderation for universal interest, was participated by more than 350 delegations from more than 70 countries. Mohd Najib in his closing official address touched on various issues related to moderation, including handling extremism, violence and acts of extremist financiers which caused adverse effects and sufferings for many parties. Mohd Najib Tun Abdul Razak also announced steps to lead efforts in developing the moderation concept to the international level (Mujani et al., 2014b). 


\section{Concluding Remarks}

Various methods have been put forward to make Malaysia peaceful and tranquil from all kinds of extremism which is increasingly disturbing to the world today. The concept of Wasatiyyah established by the Prime Minister of Malaysia is closely interconnected with efforts of the Malaysian government which desires that all Malaysians live in peace and harmony despite differences in race and faith. This is compatible with the history of any religion in this world which does not allow hostilities and fighting in living within a country. The concept of Wasatiyyah in the 1Malaysia Concept has given moderation and equality to every aspect, for example, the 1Malaysia Assistance Programme gives a chance to all eligible Malaysians to receive assistance. In conclusion, we actually have been entrusted to preserve this country and to avert from any undesirable adverse events.

\section{References}

Abdul Majid, M. Kamil. (2004). Islam Hadhari dari perspektif pemikiran Islam (Islam Hadhari from the perspective of Islamic thought). Working paper in International Seminar on Islam Hadhari. Organized by Academy of Islamic Studies, Universiti of Malaya, Kuala Lumpur, November 24-25.

Abdulkarim Amrullah, Abdulmalik. (1982). Tafsir al-Azhar. Singapura: Pustaka Nasional Pte. Ltd.

Basmeih, Abdullah. (2001). Tafsir Pemimpin Ar-Rahman kepada Pengertian al-Qur'an. Kuala Lumpur: Darul Fikir.

Basri, Ghazali. (2008). DinamikaTasawwur Islam dalam pembentukan keperibadian umat (The dynamic of Tasawwur Islam in the formation of Ummah character). Bandar Seri Begawan, Brunei: Pusat Penerbitan Kolej Universiti Perguruan Ugama Seri Begawan.

Hashem, A. Omar. (2006). Moderation in Islam. N.p.: n.p.

Hassan, M. Haniff. (2003). Muslim moderat warga Singapura (Moderate Muslim of Singapore). Singapura: Perdaus dan Lembaga Pentadbir Masjid al-Khair.

Ibn Kathir, Abu al-Fida Ismail. (2003). Tafsir Ibn Kathir. Trans. Shaykh Safiur-Rahman Al-Mubarakpuri. Riyadh, Saudi Arabia: Darussalam.

Ismail, M. Khuzairi. (2012). Institut Wasatiyah ditubuh (The Institute of Wasatiyah was formed). In Utusan Melayu, January 18.

Kling, Zainal. (2011). Konsep Wasatiyyah: perspektif sains sosial (Wasatiyyah concept: social science perspectives). Working paper in Convention of Wasatiyyah in conjunction with the millennium of Islam in Malay archipelago. Organized by Unversiti Sains Islam Malaysia, Putrajaya, June 9.

M. Adil, M. A. (2010). 1Malaysia: satu analisis dari perspektif Perlembagaan Persekutuan (1Malaysia: an analysis from the perspective of the Federal Constitution. Working paper in National Seminar on 1Malaysia. Organized by Pusat Penataran IImu dan Bahasa, Universiti Malaysia Sabah (UMS), Sabah, November 1-3.

M. Khambali@Hambali, Khadijah et al. (2010). Pendekatan Wasatiyyah dalam pengaplikasian Islam Hadhari di dalam memperkasa misi 1Malaysia (Wasatiyyah approach in the application of Islam Hadhari in strengthening the 1Malaysia mission). Working paper in National Seminar on 1Malaysia. Organized by Pusat Penataran IImu dan Bahasa, Universiti Malaysia Sabah (UMS), Sabah, November 1-3.

M. Mazuki, A.A, Mujani, W.K., Aziz, A. \& Rozali, E.A. (2013a). Application of the Wasatiyyah concept to the formation of the Medina charter. International Journal of West Asian Studies, 5(2), 1-15.

M. Mazuki, A.A, Mujani, W.K., Aziz, A. \& Rozali, E.A. (2013b). Nilai Wasatiyyah dalam Islam (The values of Wasatiyyah in Islam). In Prosiding Nadwah Ulama Nusantara (NUN) V: Ulama dan Cabaran Idealisme Semasa (Proceeding of Conference on Muslim Scholars in Malay Archipelago: Challenges of Idealism), ed. A.F. Kamaruzaman et al. Bangi: Department of Arabic Studies and Islamic Civilization, Faculty of Islamic Studies, UKM, 340-344.

M. Mazuki, A.A, Mujani, W.K., Aziz, A. \& Rozali, E.A. (2014). Hubungan etnik \& agama dengan pengetahuan terhadap konsep Wasatiyyah (The Relation between ethnic \& religious and the knowledge of Wasatiyyah concept). In Proceeding of Dakwah Talks - The Management of Contemporary Dakwah, ed. M.F Ashaari et al. Bangi: Department of Dakwah and Leadership, Faculty of Islamic Studies, UKM, 88-92.

Maslan, Ahmad. (2011). Najib rasmi Seminar Pemahaman Wasatiyyah, 1Malaysia (Najib officiate Seminar on Understand of the Wasatiyyah, 1Malaysia). Retrieved July 4, 2012, from http://www.ahmadmaslan.com/2011/11/najib-rasmi-seminar-pemahaman. html

Moner, Shamsudin. (2009). 1Malaysia, penyatuan pemikiran dan perjuangan - bahagian pertama (1Malaysia, unification of thoughts and the struggle - part one). Retrieved August 2, 2012, from http://ummatanwasatan.net/2009/07/1malaysia-penyatuan-pemikirandan-perjuangan-bhg-pertamal

Mujani, W.K., M. Mazuki, A.A., Aziz, A. \& Rozali, E.A. (2014a). Society's knowledge of Wasatiyyah (moderation) concept. In Lecture Notes in Management Science - 2014 2nd International Conference in Humanities, Social Sciences and Global Business Management (ISSGBM 2014), ed. Y. Zhang, vol.31. Singapore: Singapore Management and Sports Science Institute, PTE. LTD, 140-143.

Mujani, W.K., Rozali, E.A. \& Ismail, M.Z. (2014b). Wasatiyyah (moderate) concept: attitude of multi-ethnic society in Malaysia. In Lecture Notes in Management Science - 2014 2nd International Conference in Humanities, Social Sciences and Global Business 
Management (ISSGBM 2014), ed. Y. Zhang, vol.31. Singapore: Singapore Management and Sports Science Institute, PTE. LTD, 144-147.

Munawwir. (1986). Posisi Islam di tengah pertarungan ideologi dan keyakinan (The position of Islam in the middle of ideologies and beliefs). Surabaya, Indonesia: PT Bina IImu.

N. Salleh, N. S. S. (2011). Wasatiyyah satukan penduduk berbilang bangsa di Malaysia (Wasatiyyah united multi-ethnic population in Malaysia). In Berita Harian, June 9.

National Policy Publications Division. (2010). 1Malaysia: Rakyat Didahulukan Pencapaian Diutamakan (1Malaysia: People First, Performance Now). Retrieved August 2, 2012, from http://www.kpkk.gov.my/pdf/1Malaysia_booklet_edisi_terbaru.pdf

Omar Khalid, Salahuddin Abdullah. (2009). Tafsir Mubin. Kuala Lumpur: Dewan Bahasa dan Pustaka.

Qutb, Sayyid. (2000). Tafsir fi Zilalil Qur'an. Trans. Yusoff Zaky Yacob. Kota Bharu, Kelantan: Pustaka Aman Press Sdn. Bhd.

Shihab, M.Quraish. (1996). Wawasan al-Quran Tafsir Maudhu'i atas pelbagai persoalan umat (Vision al-Quran Tafsir Maudhu'i on various people issues). Bandung, Indonesia: Penerbit Mizan.

Sya'rawi, Syekh Muhammad Mutawwali. (2004). Tafsir Sya'rawi. Trans. Tim Safir al-Azhar. Jakarta, Indonesia: Penerbit Duta Azhar. 